\title{
Notícia: Alvaro Tamayo
}

\author{
Juliana Barreiros Porto ${ }^{1}$ \\ Universidade Católica de Brasília
}

\section{News: Alvaro Tamayo}

Dia 02 de setembro de 2007 um grande pesquisador latino-americano em Psicologia Social e Organizacional, Alvaro Tamayo, nos deixou um legado de importantes idéias, reflexões e proposições teóricas e metodológicas para a Psicologia Social. Espero que este texto faça jus à sua memória e possa divulgar àqueles que não o conheceram suas principais contribuições e relembrar aos amigos, colegas e alunos alguns ensinamentos que ele nos deixou.

Tamayo era colombiano, mas sua trajetória permitia que ele fosse considerado um cidadão do mundo. Fez sua formação em Psicologia (graduação, mestrado e doutorado) na Universidade Católica de Louvain na Bélgica, foi professor no Canadá e Brasil e realizou intercâmbio científico com pesquisadores de vários locais do mundo, apenas para citar alguns: Alemanha, Espanha e Israel. Veio para o Brasil em 1978 com a missão de construir, em conjunto com outros professores, a pós-graduação em Psicologia da Universidade de Brasília. Permaneceu nessa universidade até a sua aposentadoria em 2004, quando passa a ser professor na Universidade Católica de Brasília e permanece como pesquisador associado da UnB. Dia 23 de março de 2006 recebeu o título de Professor Emérito da UnB como reconhecimento à importância do trabalho realizado para o desenvolvimento da universidade e da ciência. Ao longo de sua carreira publicou 80 artigos científicos, organizou cinco livros e escreveu mais de 20 capítulos. Até seus últimos dias, participou ativamente das atividades acadêmicas e contribuiu de forma significativa para o desenvolvimento de mestres e doutores Brasil a fora.

No início de sua carreira ele desenvolve o tema do seu doutoramento, estruturas simbólicas de imagens parentais, e as suas publicações refletem esses estudos. Quando vem para o Brasil, seu interesse passa a ser o estudo do autoconceito, tema que desenvolverá até final da década de 1980. Nessa época, durante um congresso internacional, ele toma conhecimento do desenvolvimento da Teoria de Valores por Shalom Schwartz e Wolfgang Bilsky e percebe o seu potencial. Imediatamente se vincula ao grupo internacional e passa a desenvolver esse tema até o final de sua vida. Como pesquisador maduro, foi nessa área que apresentou suas principais contribuições à Psicologia.

Inicialmente Tamayo se dedicou aos estudos sobre a relação entre valores e comportamento. Assim, desenvolveu diversas pesquisas que visavam subsidiar a compreensão do comportamento humano e ações mais efetivas para resolu-

1 Endereço: SEPS 714/914 Bloco E, Sala 107, Ed. Talento, Brasília, DF, Brasil 70390-145.E-mail: porto.juliana@gmail.com ção de problemas sociais, como consumo de drogas e uso de preservativos por adolescentes. Além disso, também tinha interesse em conhecer quem é o brasileiro e dessa forma realiza estudos sobre os valores dos brasileiros. Praticamente 10 anos após o início dos estudos em valores, ele aplica esse conhecimento às organizações e passa os 10 anos seguintes desenvolvendo a Teoria dos Valores Organizacionais. Vários avanços foram dados por ele para a elaboração de uma estrutura que permitisse compreender esse aspecto da cultura organizacional. Entretanto, seu trabalho também se destaca pela sua defesa à importância da consideração dos valores dos funcionários por parte da organização, para o estabelecimento de vínculos saudáveis e a promoção do bem-estar. Nas palavras de Tamayo (2005, p.170):

Por baixo deste aspecto metalizado (busca de lucros pelas organizações), porém, existe um mundo de ilusões, de desejos, de sentimentos, de paixões, de aspirações e de frustrações que representam todo o aspecto motivacional do trabalho e que a organização não pode ignorar.

Eram esses aspectos que ele buscava desvendar por meio de suas pesquisas.

Como professor formou 23 mestres e 12 doutores que vêm divulgando o seu trabalho por todo o país. Neste particular, ele nos ensinou não só o fazer científico como também a sabedoria em saber ouvir, respeitar a opinião do outro, ter serenidade, ser afetuoso e receptivo, esperar o momento certo de cada um e ser humilde. Como orientador gerava a dúvida necessária em seus orientandos para que pudessem construir de forma independente o seu pensamento, mas também gerava a confiança necessária para que pudessem prosseguir na caminhada.

Seu gosto pelo ensino sempre transpareceu no seu trabalho, ele não escondia o seu prazer em ensinar Psicologia Social para os "calouros". Como professor encantava pela sua serenidade e capacidade de reflexão. Suas aulas sempre levavam a discussões instigantes e a sua imparcialidade era fundamental. Era preciso que cada um tirasse as suas conclusões, jamais se poderia esperar uma resposta pronta vinda dele. E o seu acolhimento às diversas opiniões dos alunos era um incentivo à nossa capacidade de pensar.

O seu grupo de pesquisa em Valores e Comportamento formado por alunos, profissionais e ex-alunos foi criado há mais de 10 anos e permanece ativo na busca por divulgar seus últimos trabalhos. Como pesquisador, se destacou pela qualidade do uso do método, pela relevância das suas pesquisas e pela formação de pesquisadores em Psicologia Social e do Trabalho. Além disso, formou e disseminou o interesse pelo estudo dos valores por todo o Brasil. Hoje é 
possível localizar pesquisadores em praticamente todas as regiões do país que foram influenciados pela sua obra.

Para concluir, cabe lembrar que ele também desempenhou importante papel no desenvolvimento e consolidação de cursos de graduação e pós-graduação em Psicologia. Ele exerceu diversos cargos administrativos e foi um dos responsáveis pelo desenvolvimento do programa de pós-graduação da Universidade de Brasília e pelo aprimoramento do curso de mestrado da Universidade Católica de Brasília. Suas reflexões foram fundamentais para a construção da Psicologia e resolução de impasses por onde quer que tenha passado.

Ficamos com esses presentes que ele nos deixou e com a esperança que as sementes por ele plantadas possam florescer ainda mais. Alvaro, muito obrigada!

Agradeço imensamente à Psicologia: Teoria e Pesquisa pelo convite para prestar essa homenagem e pela oportunidade de expressar todo o meu reconhecimento e gratidão ao mestre. Agradeço também à Profa. Maria das Graças Torres da Paz pelos comentários às versões anteriores deste texto.

\section{Referência}

Tamayo, A. (2005). Impacto dos valores pessoais e organizacionais sobre o comprometimento organizacional. Em A. Tamayo \& J. B. Porto (Orgs.), Valores e comportamento nas organizações (pp. 160-186). Rio de Janeiro: Vozes.

Recebido em 20.09.2007

Aceito em 25.10.2007 